\title{
Brief Communication: A new perspective on the Australian rip current hazard
}

\author{
R. Brander ${ }^{1}$, D. Dominey-Howes ${ }^{2}$, C. Champion ${ }^{1}$, O. Del Vecchio ${ }^{1}$, and B. Brighton ${ }^{3}$ \\ ${ }^{1}$ School of Biological, Earth and Environmental Sciences, The University of New South Wales, Sydney, NSW 2052, Australia \\ ${ }^{2}$ School of Geosciences, The University of Sydney, Sydney, NSW 2006, Australia \\ ${ }^{3}$ Surf Life Saving Australia, Locked Bag 1010, Rosebery, NSW 2018, Australia
}

Correspondence to: R. Brander (rbrander@unsw.edu.au)

Received: 5 December 2012 - Published in Nat. Hazards Earth Syst. Sci. Discuss.: Revised: 8 April 2013 - Accepted: 25 May 2013 - Published: 28 June 2013

\begin{abstract}
Rip currents are strong, narrow offshore flows of water which occur on many of the world's beaches and represent a serious hazard to bathers. In Australia, rip currents account for an average of 21 confirmed human fatalities per year. Based on an analysis of the longest existing data records, rip currents account for more human fatalities in Australia on average each year than bushfires, floods, and cyclones combined. This finding raises important questions regarding the levels of attention placed on the low intensity, but high frequency rip current hazard in relation to high profile and episodic natural hazards.
\end{abstract}

\section{Introduction}

Natural hazards have the capacity to cause significant loss of human life, injury, damage and disruption to human systems (Guha-Sapir et al., 2012). Some natural hazards (e.g. bushfires, floods, tsunamis) are defined as "rapid" or "sudden onset" and may assume a particularly high public profile, especially when they claim a significant number of human lives. In contrast, others (e.g. drought, tropical cyclones) are "slow onset" or creeping hazards. Individual events may or may not cause large loss of human life. Regardless of the suddenness of onset or otherwise, the loss of human life is a significant issue - one that focuses the attention of emergency risk managers, government officials, the general public, the media and other relevant and interested stakeholders. The precise number of human fatalities each year associated with natural hazard events is both difficult to measure and contested. The annual average may be rising or falling. However, according to the World Health Organization's Centre for Research on the Epidemiology of Disasters (CRED) in 2011, there were just over 30000 natural hazard fatalities globally (Guha-Sapir et al., 2012) - a number well below the 1980-2010 annual average of $70000+$ (Worldwatch Institute, 2012).

Australia is regularly affected by numerous natural hazards that result in significant loss of life (ABS, 2008). Many of these events receive widespread global media attention (ABC News, 2009, 2010). With more than $80 \%$ of a population of 22.6 million living within $50 \mathrm{~km}$ of the coastline (CSIRO, 2011), Australia may be defined as a coastal nation. Furthermore, and perhaps more importantly, Australia is a country whose socio-cultural identity is closely associated with the beach and surf (Hammer, 2012). This is true for both domestic residents and tourists alike. However, it is often overlooked and under-reported that many of Australia's beaches come with inherent natural hazards themselves, particularly rip currents (Short and Hogan, 1994; Short, 2007). Rip currents are strong, narrow seaward flowing currents that can easily carry unsuspecting swimmers from the shoreline significant distances offshore, leading to exhaustion, panic and often drowning (Brander et al., 2011; Drozdzewski et al., 2012). Rip currents are a global problem and are considered to be a major hazard facing bathers at beaches where they occur (Klein et al., 2003; Scott et al., 2009; Brander and MacMahan, 2011), but they are particularly ubiquitous features on Australia's approximately 11000 mainland beaches with an estimated 17500 operating at any given time (Short, 2007).

It has traditionally proven difficult to accurately quantify the number of annual drowning deaths and rescues attributed 
Table 1. Average number of fatalities per year attributed to different natural hazards in Australia based on the longest available datasets.

\begin{tabular}{llrr}
\hline $\begin{array}{l}\text { Natural } \\
\text { Hazard }\end{array}$ & $\begin{array}{l}\text { Database } \\
\text { Period }\end{array}$ & $\begin{array}{r}\text { Total } \\
\text { Fatalities }\end{array}$ & $\begin{array}{r}\text { Fatalities/ } \\
\text { Year }\end{array}$ \\
\hline Cyclones & $1887-2012$ & 936 & 7.5 \\
Floods & $1852-2012$ & 685 & 4.3 \\
Bushfires & $1898-2012$ & 672 & 5.9 \\
Sharks & $1962-2012$ & 50 & 1 \\
Rip Currents & $2004-2011$ & 142 & 21 \\
\hline
\end{tabular}

to rip currents due to the logistical constraints in obtaining meaningful incident reports. For example, based on an analysis of natural hazard and media report databases, Gensini and Ashley (2009) suggested that an average of 35 people per year drown in rip currents on beaches in the United States. This is in contrast to the commonly reported approximate value of 100 by the United States Lifesaving Association (USLA; Brewster, 2010) and 150 reported by Lushine (1991). A similar situation exists in Australia with various studies (Sherker et al., 2008; Brander and MacMahan, 2011) suggesting that anywhere from 40 to 60 people drown in rip currents each year. However, these numbers are largely speculative assumptions based on anecdotal information. A recent study by Surf Life Saving Australia, Australia's largest beach safety organisation, using Australia's National Coronial Information System (NCIS) and Media Monitors for the period 1 July 2004 to 20 June 2011 has revealed that the average annual number of confirmed rip current fatalities during this period is $21 \mathrm{yr}^{-1}$ (Brighton et al., 2013). However, they acknowledged that this number is very likely to be an underestimate as fatalities are only recorded as being rip current related when there is a witness to the event who describes the individual being caught in a rip current. This description must then be included in electronically available coronial reports. Nevertheless 21 fatalities represents a significant number of avoidable beach drowning deaths in Australia each year.

The rip current hazard in Australia is an example of a high frequency, low intensity hazard that is almost always present, but only occasionally results in more than one simultaneous fatality. As such, it has not been considered in context or compared with more catastrophic and episodic natural hazards that affect Australia and its people. That is, there may be a lower collective perception of the risk of rip currents in comparison to other hazard types that have the capacity to claim larger numbers of lives in a single event (such as bushfires). The question that arises is "are rip currents claiming more lives in Australia than other more prominent natural hazard types?" The answer to this question is significant for two reasons. First, a lack of robust empirical data on actual rip current fatalities stands as a fundamental obstacle for developing appropriate risk reduction strategies in
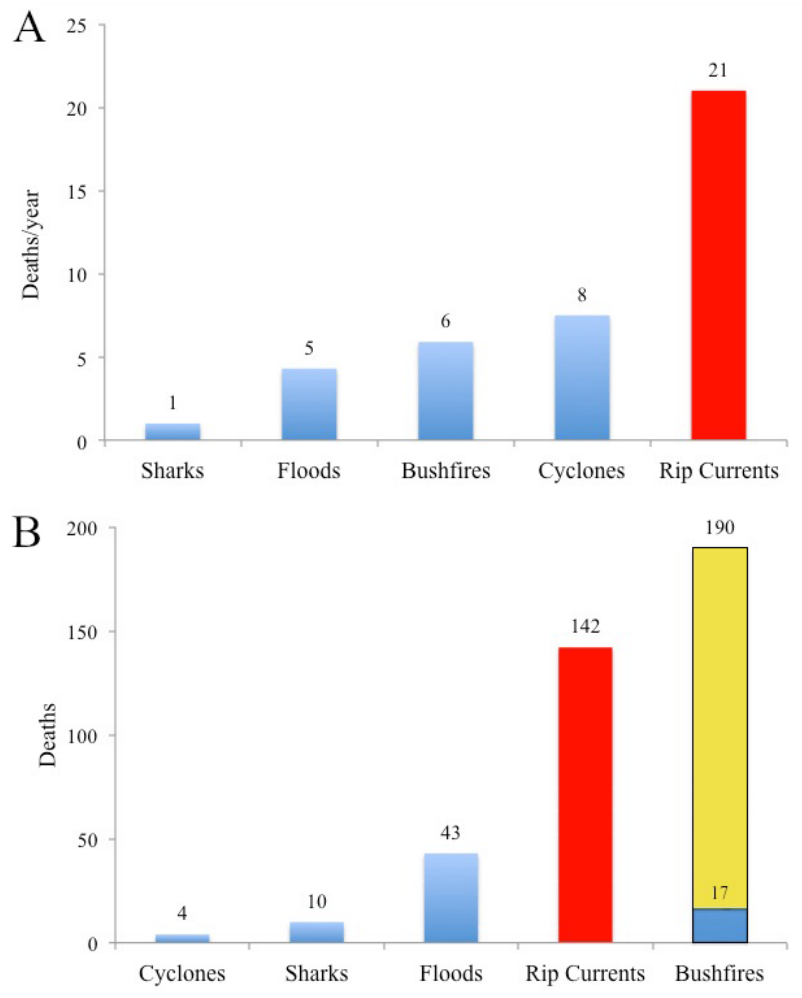

Fig. 1. A comparison of average annual fatalities by natural hazards in Australia for (a) the longest available datasets and (b) the overlapping period 2004-2011. Note that the yellow band corresponds to fatalities in a single bushfire event on 9 February 2009.

Australia. Second, the level of funding allocated in Australia to rip current education and awareness programs and risk management may be significantly lower than the levels of funding provided to other more prominent hazards that may actually claim less lives on an average annual basis. Here we seek to "benchmark" the annual number of rip current fatalities in Australia against the most commonly occurring natural hazard types in order to provide a better assessment of the "relative" risk posed by rip currents within a national context.

\section{Contextualising the rip current hazard}

We compare the best available data of annual rip current fatalities ( $n=21 \mathrm{yr}^{-1}$; Brighton et al., 2013) in relation to the long-term average of human fatalities caused by the following natural hazards: (1) tropical cyclones; (2) bushfires; (3) floods; and (4) shark attacks. The first three hazards were chosen as they are the most commonly occurring types in Australia (Middelmann, 2007) and are all hydrometeorological by classification. Shark attacks are included as they are also ocean based (like rips), are a hazard to human life over which individuals have little control, and which have a high 
Table 2. Average number of fatalities per year attributed to different natural hazards in Australia based on overlapping datasets for the period 2004-2011. Bushfire statistics in parentheses do not include the bushfire event of 9 February 2009.

\begin{tabular}{lll}
\hline Natural Hazard & Total Fatalities & Fatalities/Year \\
\hline Cyclones & 4 & 0.6 \\
Floods & 43 & 6.1 \\
Bushfires & $190(17)$ & $27.1(2.4)$ \\
Sharks & 10 & 1.4 \\
Rip Currents & 142 & 21 \\
\hline
\end{tabular}

public profile and significant associated "fear factor" $(\mathrm{CNN}$ News, 2011).

Human fatality data for tropical cyclones, bushfires and floods were sourced from the Australian Emergency Management Institute National Disaster Database (AEMI, 2012), which represents the most comprehensive source of this information. The length of time series for each hazard type is indicated in Table 1. The most complete source of shark fatality data is the Australian Shark Attack File administered by the Taronga Zoo, Sydney, Australia (West, 2012). A summary of the data is provided in Table 1 and illustrated in Fig. 1a. Based on these results, the rip current hazard accounts for more average annual fatalities $(n=21)$ in Australia than cyclones $(n=7.5)$, bushfires $(n=5.9)$, floods $(n=4.3)$ and sharks $(n=1)$ combined $(n=18.7)$.

The annual averages for the different hazards are determined over different time periods ranging from $7 \mathrm{yr}$ for rip currents to $160 \mathrm{yr}$ for floods (Table 1). Many factors, such as population and exposure to risk, change over time, making direct comparisons of fatality rates based on different timeseries lengths difficult. We therefore compared fatalities for all of the hazards over the overlapping $7 \mathrm{yr}$ period 20042011, and a summary of the data is provided in Table 2 and Fig. 1b. It is clear that over the comparable period, bushfires were the dominant hazard in Australia in terms of fatalities ( $n=27.1 \mathrm{yr}^{-1}$; Table 2; Fig. 1b). However, this period included the tragic "Black Saturday" bushfires in the outskirts of Melbourne, Victoria, on 7 February 2009, which claimed the lives of 173 people. If this event had not occurred in this time period, the average annual number of fatalities from bushfires per year would decrease from 27.1 to 2.4. In this case, the annual average number of fatalities due to rip currents $\left(n=21 \mathrm{yr}^{-1}\right)$ is double the annual average fatalities of the other hazards combined $\left(n=10.5 \mathrm{yr}^{-1}\right)$. This comparison illustrates the potential bias of using short-term datasets to compare average annual fatalities between catastrophic event-based hazards associated with large loss of life, such as bushfires, and low magnitude and ambient hazards which cause persistent, but small, loss of life, such as rip currents.

The implications of this first pass analysis of average annual fatality data indicate that rip currents are claiming more lives in Australia in the long term than other more high profile natural hazard types. It should be noted that fatalities resulting from extreme heat, which are likely greater than those caused by rip currents, were not included here as heat is defined as a slow onset natural hazard type. The omission of heat-related deaths is not uncommon in analysis of natural hazard fatalities given the complexity of the issue and interrelated factors affecting heat-related mortality (Worldwatch Institute, 2012).

\section{Conclusions}

The findings presented here show that the rip current hazard needs to be considered in a new perspective when it comes to loss of life in Australia by natural hazards. In particular, further consideration should be given to the relative levels of funding and media attention devoted to the rip current hazard, which may not result in catastrophic episodes of high human loss events and property damage like other natural hazards, but over the long term accounts for greater overall loss of human life. As rip currents are a global problem, it is hoped that this study can be applied in other countries to more appropriately place the rip current hazard in perspective with and context of other natural hazard types.

Acknowledgements. This study was supported by funding from two Australian Research Council (ARC) grants: ARC LP 110200134 (Brander) and ARC DP 130100877 (Dominey-Howes).

Edited by: N. Pinardi

Reviewed by: A. Lamberti and Y. N. Krestenitis

\section{References}

Australian Broadcasting Corporation (ABC) News Online: Catastrophic fire warning confuses residents, available at: http://www. abc.net.au/news/stories/2009/11/18/2746064.htm (last access: 3 December 2012), 2009.

Australian Broadcasting Corporation (ABC) News Online: Swimmers may not understand tsunami risk, available at: http: //www.abc.net.au/science/articles/2010/03/01/2833326.htm (last access: 3 December 2012), 2010.

Australian Bureau of Statistics (ABS): Year Book, Australia 2008, Feature Article 3: Understanding natural hazard impacts in Australia, available at: http://www.abs.gov.au/ausstats/ abs@.nsf/Previousproducts/1301.0Feature\%20Article42008? opendocument $\&$ tabname $=$ Summary $\&$ prodno $=1301.0 \&$ issue $=$ 2008\&num=\&view= (last access: 30 November 2012), 2008.

Australian Emergency Management Institute (AEMI): Emergency Management Database, Australia Government AttorneyGeneral's Department, available at: http://www.disasters.ema. gov.au/Browse/Categories.aspx (last access: 21 November 2012), 2012.

Brander, R. and MacMahan, J.: Future challenges for rip current research and outreach, in: Rip Currents, Beach Safety, Physical 
Oceanography and Wave Modeling, edited by: Leatherman, S. and Fletemeyer, J., CRC Press, Boca Raton, FL, 1-29, 2011.

Brander, R., Bradstreet, A., Sherker, S., and MacMahan, J.: Responses of swimmers caught in rip currents: Perspectives on mitigating the global rip current hazard, Int. J. Aqua. Res. Educ., 5, 476-482, 2011.

Brewster, B. C.: Rip current misunderstandings, Nat. Hazards, 55, 161-162, doi:10.1007/s11069-010-9527-4, 2010.

Brighton, B., Sherker, S., Brander, R., Thompson, M., and Bradstreet, A.: Rip current related drowning deaths and rescues in Australia 2004-2011, Nat. Hazards Earth Syst. Sci., 13, 10691075, doi:10.5194/nhess-13-1069-2013, 2013.

CNN News: Putting Australia's shark attacks in perspective, available at: http://edition.cnn.com/2011/10/27/opinion/ australia-shark-attacks/index.html (last access: 3 December 2012), 2011.

CSIRO (Commonwealth Scientific and Industrial Research Organisation): Our resilient coastal Australia, available at: http://www.csiro.au/en/Organisation-Structure/Flagships/

Wealth-from-Oceans-Flagship/ORCA.aspx, last access: 3 December 2012.

Drozdzewski, D., Shaw, W., Dominey-Howes, D., Brander, R., Walton, T., Gero, A., Sherker, S., Goff, J., and Edwick, B.: Surveying rip current survivors: preliminary insights into the experiences of being caught in rip currents, Nat. Hazards Earth Syst. Sci., 12, 1201-1211, doi:10.5194/nhess-12-1201-2012, 2012.

Gensini, V. and Ashley, W.: An examination of rip current fatalities in the United States. Nat. Hazards, 54, 159-175, doi:10.1007/s11069-009-9458-0, 2009.

Guha-Sapir, D., Vos, F., Below, R., and Ponserre, S.: Annual Disaster Statistical Review 2011: the numbers and trends, Centre for Research on the Epidemiology of Disasters (CRED), Brussells, 52 pp., 2012.
Hammer, C.: The Coast, Melbourne University Press, Melbourne, 1st Edn., 237 pp., 2012.

Klein, A. H. da F., Santana, G. G., Diehl, F. L., and de Menezes, J. T.: Analysis of hazards associated with sea bathing: results of five years' work in oceanic beaches of Santa Catarina State, Southern Brazil, J. Coastal Res., 35, 107-116, 2003.

Lushine, J. B.: A study of rip current drownings and weather related factors, Nat. Weather Dig., 16, 13-19, 1991.

Middelmann, M. H. (Ed.): Natural Hazards in Australia: Identifying Risk Management Requirements, Geoscience Australia, Canberra, 173 pp., 2007.

Scott, T. M., Russell, P. E., Masselink, G., and Wooler, A.: Rip current variability and hazard along a macro-tidal coast, J. Coastal Res., SI 56, 895-899, 2009.

Sherker, S., Brander, R., Finch, C., and Hatfield, J.: Why Australia needs an effective national campaign to reduce coastal drowning, J. Sci. Med. Sport, 11, 81-83, 2008.

Short, A. D.: Australian rip systems: friend or foe?, J. Coastal Res., SI 50, 7-11, 2007.

Short, A. D. and Hogan, C.: Rip currents and beach hazards: their impact on public safety and implications for coastal management, J. Coastal Res., 12, 197-209, 1994.

West, J.: Australian Shark Attack File, Taronga Conservation Society Australia, available at: http://www. taronga.org.au/animalsconservation/conservationscience/ australian-shark-attack-file/latest-figures (last access: 21 November 2012), 2012.

Worldwatch Institute (WWI): Losses from natural disasters reach new peak in 2011, available at: http://www.worldwatch.org/ losses-natural-disasters-reach-new-peak-2011 (last access: 21 November 2012), 2012. 